JURNAL 『ERKNOSAINS

VOLUME 3

No. 2, 22 Juni 2014

Halaman 81-166

\title{
PERKEMBANGAN LAYANAN TRANSPORTASI PERDESAAN PADA WILAYAH BERBUKIT
}

\author{
Dewanti dan Danang Parikesit \\ Jurusan Teknik Sipil dan Lingkungan \\ Fakultas TeknikUniversitas Gadjah Mada \\ Email: dewanti_marsoyo@yahoo.com \\ Achmad Djunaedi \\ Jurusan Teknik Arsiektur dan Perencanaan \\ Fakultas Teknik Universitas Gadjah Mada
}

\begin{abstract}
Transport services development generally indicates some development problems and transport troubles in particular. This research analyses the development of rural transport services in Kemalang Sub-district, Klaten District, Central Java Province using qualitative research method and adopts Case Study research approach. Primary data were collected by in-depth interviewing to 26 informants and supported by secondary data from institusional survey. Transport service development was reviewed in three development stages, those are before 1990, 1990-2005 and 2005-2010. There have been usage alterations of dominant transport service during those three periods, from unmotorized private transport service to motorized public transport services and then has changed to private transport services of motor cycle. That development leads positive changes on the character of transport service, such as the increase of transport service availability, flexibility and capability in solving nature restrictions so that promote mobility and accessibility. One negative change is traffic safety decrease.
\end{abstract}

Keywords: Transportation services, Rural, Hilly region.

\begin{abstract}
ABSTRAK
Perkembangan layanan transportasi dapat mengindikasikan berbagai permasalahan pembangunan pada umumnya dan permasalahan transportasi pada khususnya. Penelitian ini mengkaji perkembangan layanan transportasi perdesaan di kecamatan Kemalang, Kabupaten Klaten, Propinsi Jawa Tengah dengan metode penelitian kualitatif dengan pendekatan penelitian Studi Kasus. Data primer diperoleh dari wawancara mendalam terhadap 26 informan serta didukung data sekunder dari survei instansional. Perkembangan layanan transportasi dikaji dalam tiga tahap perkembangan, yaitu sebelum tahun 1990, pada tahun 1990-2005 dan tahun 2005-2010. Selama tiga periode perkembangan tersebut terjadi perubahan penggunaan layanan transportasi yang dominan, yaitu dari layanan transportasi pribadi dengan kendaraan tidak bermotor berubah ke layanan transportasi umum bermotor dan berkembang menjadi layanan sepeda motor. Perkembangan tersebut memberikan perubahan positif pada karakter layanan transportasi, berupa peningkatan ketersediaan layanan, fleksibilitas, kemampuan mengatasi kendala alam yang bermuara pada peningkatan mobilitas masyarakat dan aksesibilitas wilayah.
\end{abstract}


Satu perubahan negatif, berupa penurunan keselamatan lalu-lintas.

Kata Kunci: Layanan transportasi, Perdesaan, Wilayah berbukit.

\section{PENGANTAR}

Wilayah perdesaan sering digambarkan sebagai wilayah dengan aksesibilitas dan mobilitas rendah (Starkey, dkk, 2002). Secara umum sarana transportasi di wilayah perdesaan memiliki variasi lebih besar dibanding wilayah perkotaan (Dewanti, dkk. , 2013). Berbagai jenis kendaraan yang beroperasi di suatu wilayah pada dasarnya merupakan perwujudan perkembangan layanan transportasi di wilayah tersebut. Salah satu faktor yang mempengaruh perkembangan layanan transportasi tersebut adalah topografi wilayah (Starkey, dkk, 2002). Wilayah perdesaan dengan topografi berbukit memiliki hambatan yang lebih besar dalam penyediaan sarana prasarana transportasi. Keberadaan berbagai layanan transportasi akan mempengaruhi mobilitas masyarakat dan aksesibilitas wilayah. Porter (2013) melihat adanya dampak layanan transportasi perdesaan di Africa yang didominasi oleh penggunaan kendaraan tidak bermotor terhadap peningkatan kesejahteraan masyarakat meskipun muncul kendala yang dihadapi sebagian masyarakat yang tidak memiliki akses ke layanan kendaraan bermotor atau angkutan umum. Sementara itu, perkembangan layanan transportasi perdesaan di negara-negara maju memunculkan 'car culture' (Nutley, 2005) dan berdampak pada berkembangnya eksklusi sosial (Halden, 2002) serta perubahan karakter pergerakan masyarakat. Dari fakta di atas, memunculkan pertanyaan "Bagaimanakah perkembangan layanan transportasi perdesaan di Indonesia, khususnya di wilayah berbukit dan bagaimana dampak perkembangan tersebut terhadap karakter layanan transportasi? Selama ini, berbagai studi di bidang transportasi perdesaan lebih berorientasi pada isu-isu pembangunan dan pemeliharaan jalan, evaluasi ekonomi proyek jalan, serta dampak ekonomi-sosial peningkatan jalan (Johnston, 2007). Di Indonesia studi yang terkait dengan layanan transportasi perdesaan masih terbatas pada karakter layanan angkutan umum menggunakan bis atau "mini-van" belum dikaitkan dengan dampaknya terhadap pergerakan masyarakat. Oleh karena itu, penelitian ini dilakukan dengan tujuan mengetahui pola perkembangan layanan tranportasi perdesaan dan dampak yang ditimbulkan terhadap karakter layanan transportasi.

Infrastruktur dan layanan transportasi perdesaan seringkali memiliki kinerja buruk dan diperparah oleh rendahnya kepadatan penduduk, terbatasanya fasilitas dan layanan umum serta lokasi tempat tinggal yang menyebar sehingga berpengaruh terhadap kesulitan akses dan pelayanan angkutan yang tidak efisien (Starkey, dkk, 2002; Williams dan White, 2001). Aksesibilitas buruk tidak hanya berkaitan dengan kemudahan mendapatkan layanan transportasi tetapi juga akses ke layanan sosial dan ekonomi (Donges, 2001). Masyarakat perdesaan di Asia dan Afrika menghabiskan waktu perjalanan cukup besar untuk perjalanan sehari-hari dalam memenuhi kebutuhan dasar (Sarkar dan Ghosh, 2000, dan Porter, 2002). Kondisi ini mengindikasikan bahwa wilayah perdesaan tersebut tidak mendapatkan layanan transportasi umum maupun kendaraan bermotor yang dapat memperpendek waktu tempuh. Menurut Owen bahwa melihat perkembangan transportasi dari perubahan teknologi kendaraan, berawal dari kendaraan tidak bermotor hingga mekanisasi kendaraan yang menghasilkan kecepatan tinggi (Owen, 1987). Perkembangan transportasi perdesaan di Inggris (kelompok negara maju) bermula dari dominasi penggunaan angkutan umum hingga tahun 1950-an, diikuti dengan peningkatan kendaraan pribadi (mobil). Pada tahun 1960 upaya untuk mempertahankan transportasi umum tidak berhasil. Muncul 
layanan transportasi berbasis komunitas dan bersifat sukarela (community and voluntary transport) pada tahun 1970 hingga saat ini (Rural Development Commission,1996). Pola perkembangan transportasi yang sama terjadi di Irlandia utara, meskipun dengan periode waktu perkembangan lebih akhir (Nutley, 2005). Bagi wilayah-wilayah negara yang sedang berkembang di Afrika, perkembangan layanan transportasi masih terbatas pada layanan kendaraan tidak bermotor dan berjalan kaki. Angkutan umum bermotor dijumpai di jalan-jalan utama desa saja yang berjarak cukup jauh dari permukiman (Porter, 2013)

Penelitian dilakukan dengan menggunakan pendekatan Kualitatif dan strategi penelitian studi kasus yang dikembangkan oleh Yin (Yin, 2009). Studi kasus digunakan untuk penelitian dengan pertanyaan penelitian 'bagaimana' dan atau 'mengapa' serta untuk meneliti peristiwa kontemporer. Peneliti memiliki peluang yang sangat kecil untuk melakukan kontrol terhadap satu peristiwa serta berusaha mengamati dalam konteks alamiah yang dibatasi oleh ruang dan waktu (Hancock dan Algozzine, 2006). Data primer yang diperlukan adalah perilaku perjalanan masyarakat dan penggunaan moda transportasi, permasalahan transportasi yang dihadapi serta upaya pemerintah maupun masyarakat dalam mengatasi permasalahan transportasi. Data tersebut diperoleh dengan wawancara mendalam (in-depth interview) kepada 26 informan yang mewakili rumah tangga dan tokoh-tokoh dari instansi terkait (Pemerintah desa, Dinas perhubungan, dan ORGANDA). Data sekunder yang mencakup kondisi sosial, ekonomi, dan fisik lingkungan wilayah diperoleh dengan survei instansional. Lokasi penelitian adalah Kecamatan Kemalang, Kabupaten Klaten, Propinsi Jawa Tengah yang terletak di kaki gunung Merapi.

Analisis data dilakukan dengan membangun konsep perkembangan layanan transportasi yang menggambarkan pola perubahan jenis kendaraan dan layanan yang dominan serta periode atau tahapan dominasi layanan tersebut. Berbagai perubahan tersebut dikelompokkan dalam tema-tema yang relevan dengan perkembangan layanan transportasi. Setiap tema dibangun penjelasan yang rinci didiskusikan dengan berbagai teori atau dibandingkan dengan kasuskasus lain yang hampir sama. Berbagai tema perkembangan layanan transportasi tersebut selanjutnya dikaji dampaknya terhadap karakter pergerakan masyarakat perdesaan.

\section{PEMBAHASAN \\ Deskripsi Lokasi Penelitian dan Layanan Transportasi yang Berkembang}

Kecamatan Kemalang di Kabupaten Klaten, Jawa Tengah memiliki karakter wilayah perbukitan. Sebagian besar wilayahnya berada di lereng Gunung Merapidengan elevasi antara 300-1. $000 \mathrm{~m}$ di atas permukaan laut (dpl). Meskipun memiliki wilayah terluas, (7,88\% wilayah Klaten), tetapi jumlah penduduknya hanya 34. 428 jiwa dengan kepadatan penduduk rendah. Sebagian besar wilayah $(98,94 \%)$ berupa tegalan, kebun, dan ladang dengan hasil pertanian menjadi salah satu sumber utama ekonomi penduduk selain penggalian pasir dan peternakan. Kondisi wilayah yang berbukit menghasilkan alinemen jalan berkelok-kelok dan naik turun. Banyak jalan rusak berat akibat beban truktruk pengangkut pasir di sepanjang jalan desa maupun kabupaten. Peta Kecamatan Kemalang dapat dilihat pada Gambar 1.

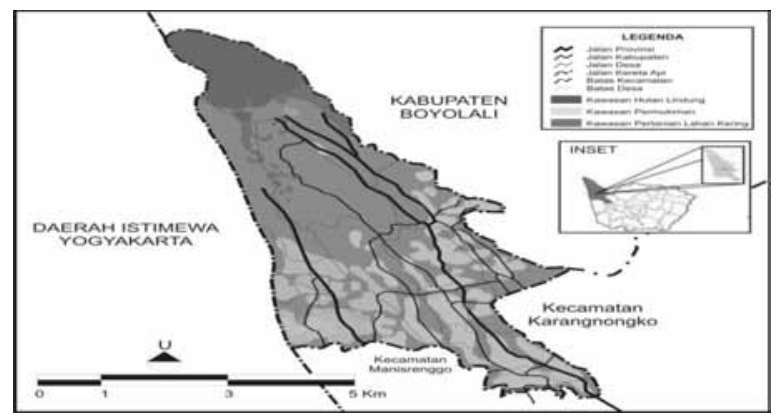

Gambar 1. Peta Kecamatan Kemalang 
Wilayah Kemalang didukung oleh jalan poros desa sebagai penghubung antardesa, sepanjang 173. $450 \mathrm{~km}$, sedangkan jalan lingkungan sepanjang 26. $100 \mathrm{~km}$. Seluruh jalan tersebut memiliki jenis perkerasanaspal, batuan yang dipadatkan, beton maupun jalan tanah. Wilayah ini dilayani oleh layanan transportasi pribadi, umum, dan sosial. Transportasi sosial banyak dijumpai di perdesaan dengan karakter gotong-royong maupun tenggang rasa cukup kuat. Layanan ini berupa saling meminjam kendaraan, berbagi kendaraan atau ikut menumpang kendaraan orang lain ketika melakukan perjalanan dengan arah/tujuan yang sama. Berbagai jenis kendaraan untuk layanan transportasi yang berkembang di wilayah penelitian pada saat ini dapat dilihat pada Tabel 1.

Tabel 1.

Jenis Layanan Transportasi dan Alat Angkut Eksisting

\begin{tabular}{l|l|l|l}
\hline \multirow{2}{*}{ Transportasi Pribadi } & \multicolumn{2}{|c|}{ Transportasi umum } & \multirow{2}{*}{ Transportasi Sosial } \\
\cline { 2 - 3 } & \multicolumn{1}{|c|}{ Formal } & \multicolumn{1}{c}{ Non-formal } & \\
\hline $\begin{array}{l}\text { Jalan-kaki, sepeda sepeda } \\
\text { motor (roda 2,3), mobil, } \\
\text { gero-bag sapi }\end{array}$ & $\begin{array}{l}\text { Bis (perdesaan) } \\
\text { Bis pariwisata }\end{array}$ & $\begin{array}{l}\text { Ojek spd motor, Mobil } \\
\text { charter/sewa, Pick-up/ } \\
\text { truck, kereta mini, mobil } \\
\text { plat hitam }\end{array}$ & $\begin{array}{l}\text { Kendaraan Pinjaman } \\
\text { giving }\end{array}$ \\
\hline
\end{tabular}

Keterangan: Mini van: L300, Isuzu

Sumber: survei lapangan, 2012.

\section{Pola Perkembangan Layanan Transportasi}

Perkembangan layanan transportasi difokuskan pada perubahan jenis kendaraan yang dominan digunakan masyarakat (dalam hal ini informan-informan penelitian) pada saat ini (tahun 2010) dan sebelumnya. Berbagai perubahan yang terjadi tersebut dikelompokkan dalam tema-tema pola perkembangan yang mewakili satu bentuk perubahan jenis kendaraan dominan, seperti pada Tabel 2.

Tabel 2.

Pola Perkembangan Layanan Transportasi Berdasarkan Cakupan Wilayah

\begin{tabular}{|c|c|c|c|c|}
\hline Cakupan wilayah & Sebelumnya & Saat ini & Perubahan & Pola \\
\hline Desa & $\dot{x}$ & & Jalan kaki ke spd. motor & Pola 1 \\
\hline \multirow[t]{2}{*}{ Kecamatan } & & & Sepeda motor ke mobil & Pola 2 \\
\hline & & & Bis kesepeda motor & Pola 3 \\
\hline \multirow[t]{2}{*}{ Kabupaten } & & & Sepeda motor ke mobil & Pola 4 \\
\hline & & ofto & Bis ke sepeda motor & Pola 3 \\
\hline \multirow[t]{2}{*}{ Luar Kabupaten } & مाII & की & Bis ke sepeda motor & Pola 3 \\
\hline & पाDा & & Bis ke mobil & Pola 5 \\
\hline
\end{tabular}

Sumber: Hasil Analisis. 
Pada berbagai cakupan wilayah ditemukan adanya lima pola perkembangan layanan transportasi (Pola 1-5). Sepeda motor mendominasi layanan transportasi saat ini, yang digunakan untuk pergerakan orang dan barang baik untuk perjalanan jarak pendek (dalam wilayah desa) maupun jarak jauh (ke luar wilayah desa). Pergerakan orang dan atau barang dalam unit keluarga biasanya menggunakan jenis kendaraan yang sama, tidak ada pemisahan secara khusus penggunaan kendaraan untuk angkutan barang (beratnya kurang dari $50 \mathrm{~kg}$ ). Di sisi lain, peran angkutan umum menurun untuk pergerakan orang di dalam wilayah desa, kecamatan, dan kabupaten; sementara orang berjalan kaki hanya pada cakupan wilayah desa saja. Pola perkembangan layanan transportasi cenderung ke pola 1 dan 3, yaitu terjadi perpindahan layanan dari berjalan kaki ke sepeda motor dan dari angkutan umum (bis) ke sepeda motor.

\section{Tahapan Perkembangan}

Perkembangan layanan transportasi juga dilihat berdasarkan tahapan perkembangan yang dianalisis dengan cara mengurutkan dan mengelompokkan berbagai informasi dari informan terkait waktu maupun periode beroperasinya suatu layanan transportasi dominan ke dalam tema tahapan perkembangan, seperti tersaji pada Tabel 3. Pada tahap pertama, hanya dengan mengandalkan berjalan kaki dalam melakukan perjalanan di daerah berbukit tentunya memberikan beban tersendiri bagi masyarakat Kemalang.

Tabel 3.

Tahapan Perkembangan Layanan Transportasi Perdesaan

\begin{tabular}{l|l}
\hline \multicolumn{1}{c|}{ Tahapan Perkembangan } & \multicolumn{1}{c}{ Dominasi Layanan Transportasi } \\
\hline Tahapan I: Sebelum 1990 & $\begin{array}{l}\text { Jalan kaki (Kendaraan tidak bermotor) untuk layanan transportasi } \\
\text { pribadi }\end{array}$ \\
\hline Tahapan II: Tahun 1990-2005 & Bis dan ojek (Kendaraan bermotor) untuk layanan transportasi umum \\
\hline Tahapan III: Tahun 2005-2010 & Sepeda motor untuk layanan transportasi pribadi \\
\hline
\end{tabular}

Sumber : Hasil analisis.

Kegiatan belajar-mengajar sering terhambat karena siswa atau guru terlam batdatang atau bahkan tidak masuk sekolah karena kendala jarak dan medan yang naik turun. Situasi ini juga menyebabkan terbatasnya jumlah pelajar yang ingin melanjutkan sekolah ke luar desa, apalagi ke luar kabupaten. Perjalanan ke pasar, ke layanan kesehatan, dan berbagai fasilitas umum memerlukan waktu dan tenaga cukup besar. Mobilitas masyarakat pada periode ini sangat rendah.

Tahap II, dominasi transportasi umum bermotor, diawali dengan munculnya layanan transportasi umum bis di Kemalang pada tahun 1987. Keberadaan layanan ini (lihat gambar 2) mampu membangkitkan jumlah perjalanan, khususnya di sepanjang rute transportasi umum yang melewati pasar, sekolah maupun fasilitas umum lainnya.
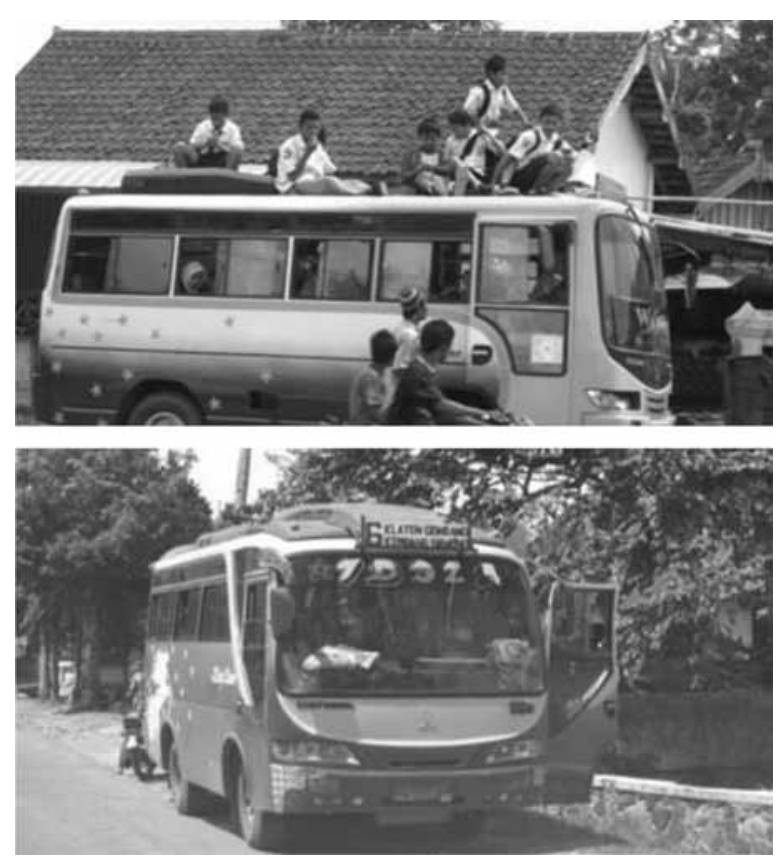

Gambar 2. Angkutan Umum Bus di Kemalang 
Situasi tersebut dijelaskan oleh Pak Srmt (sopir bis, wawancara tanggal 1 Desember 2012), yang sudah lebih 30 tahun bekerja sebagai sopir bis.

"Dulujalur ini dilayani oleh POWahyu Utomo, PO Tulus Rapi, PO Putera Daya, PO Berkah Ria. Masing-masing punya armada banyak, ada yang 4 , ada yang 3 , ada yang 2 , semuanya jalan (beroperasi). Jadi saat itu cukup ramai, tiap 10 menit ada angkutan. Jadi kalau mau ke Klaten enak sekali, setiap 10 menit sudah datang bis. Bis pertama berangkat jam 6. 15, setelah itu 15 menit berikutnya, [...] ini karena penumpang masih banyak.."

Ungkapan yang hampir sama juga disampaikan oleh pak Blm (petani, wawancara tanggal 23 Desember 2011). Bahkan pekerjaan sebagai sopir angkutan saat itu sangat membanggakan dan dapat memberi penghasilan yang memadai, seperti yang diungkap pak Srmt (sopir bis, wawancara tanggal 1 Desember 2012).

"Jadi sopir jaman sekarang tidak bisa dibanggakan, kalau jaman tahun 1990an itu 'mentereng'.... dari atas kendaraan gagah... merokok, makan tidak bayar, hasilnya bisa untuk mencukupi keluarga."

Menurut bu Lrt, sekitar tahun 1970, di Kemalang sudah berkembang taksi sepeda motor atau yang dikenal sebagai 'ojek'. Awalnya Ojek berkembang cukup pesat pada tahap perkembangan I dan pada tahap IIterjadi pergeseran area layanannya. 'Ojek' pada tahap II tetap beroperasi dengan wilayah layanan berbeda, yaitu pada wilayah yang tidak dilalui transportasi umum bis. Menurut Pak Sprn, sopir bis, antara angkutan bis dan 'ojek' tidak pernah ada konflik, masing-masing memiliki wilayah layanan yang berbeda, keduanya saling melengkapi. Keberadaan transportasi umum telah memudahkan masyarakat mengakses berbagai layanan yang lebih jauh lokasinya (misal:sekolah), lebih baik layanannya (misal: rumah sakit) maupun lebih murah harganya (misal: pasar).
Tahap III, dominasi sepeda motor. Layanan ini sudah ada di Kemalang sejak tahun 1970an, tetapi penggunaan sebagai angkutan pribadi yang dominan, merata di seluruh masyarakat baru tahun 2005. Hal ini diungkap oleh Pak Hndk, penjual sepeda motor bekas, dan diperkuat oleh pak Hyk, staf kecamatan.

"Disini ekonomi bagus, karena lapangan kerja bagus. Sepeda motor mulai kelihatan banyak tahun 2000. Namun baru tahun 2005 itu saatnya 'booming', hampir semua keluarga disini mempunyai sepeda motor. Kemana-mana orang menggunakan sepeda motor."

(Bapak Hndk, penjual sepeda motor bekas, wawancara tanggal 6 Desember 2011).

"[...] Jadi, sepeda motor di Kemalang itu berkembang semenjak galian $\mathrm{C}$ berkembang tahun 1995 dan "bego-bego" [maksudnya 'backhoe' alat berat untuk menambang pasir] muncul tahun 2000 dan sepeda motor tumbuh pesat sejak tahun 2003. Puncaknya terjadi pada tahun 2005. [...] Itu menjadi salah satu alasan kenapa angkutan umum menurun."

(Bapak Hyk, staf kecamatan, wawancara tanggal 6 Desember 2011)

Hal senada juga disampaikan oleh bu Lrt (istri pengusaha angkutan di Kemalang) bahwa sepeda motor sudah menjadi barang yang umum dimiliki setiap keluarga di Kemalang, bahkan menurut pak Byn banyak keluarga yang memiliki sepeda motor lebih dari satu. Kondisi ekonomi masyarakat Kemalang dianggap pak Hndk baik sehingga memungkinkan membeli sepeda motor dengan mudah.

"[...] Semua orang disini kalau bepergian naik sepeda motor, tidak ada yang berjalan kaki. Kondisi tersebut mulai ramai tahun 2005, saat itu di atas [maksudnya di lereng gunung] mulai banyak "bego-bego" mengambil tanah, pasir. Masyarakat dapat uang banyak untuk membeli kendaraan, anakanak sekolah banyak yang diantar naik motor atau mobil. [...] HP juga berpengaruh dalam penurunan angkutan umum, dan 
terasa sekali sekitar tahun 2005. Jadi motor dan HP berpengaruh pada tahun 2005. "

(Ibu Lrt, istri pengusaha angkutan, wawancara tanggal 6 Desember 2011).

“[...] dulu Kemalang juara 1 dalam pembelian sepeda motor, masyarakat di sini terkenal ekonominya baik karena hasil panen tembakau berhasil dan ketika di Kemalang banyak 'bego'. Orang-orang yang jadi 'Toker' (orang yang kerjaannya meratakan lahan) itu, dalam satu hari semalam bisa dapat 200 ribu... lumayan sekali. Perputaran ekonomi disini cepat sekali. Kondisi ini menyebabkan sepeda motornya 'mbludag'(banyak)."

(Bapak Byn, pemilik truck, wawancara tanggal 1 Januari 2012).

Peningkatan jumlah sepeda motor yang demikian besar tidak lepas dari keunggulan kendaraan tersebut di mata pembeli atau pengguna, seperti yang disampaikan oleh $\mathrm{Bu}$ Hni.

"Kalau angkutan umum itu ya gimana ya. Kalo disuruh milih ke Klaten naik motor atau angkutan umum ya milih naik motor karena irit, tidak menunggu terlalu lama. Kalau motor kan 'sakkarepe'(semaunya), kapanpun diperlukan bisa. Bus itu paling jam 6 pagi datang, nanti jam 3 sore itu udah tidak ada. Bus yang ke Klaten itu sekitar Rp 7.000 atau Rp 8.000, kalau uang itu dipakai buat bensin kan bisa kemana-mana. [...] Jadi, yang sulit itu ya nunggunya itu yang lama." (Bu Hni, ibu rumah tangga, wawancara tanggal 29 Desember 2011).

Sepeda motor juga digunakan untuk angkutan barang seperti yang dilakukan pedagang sayuran keliling, pak Krn dan Bu Tnk, serta penjual buah pak Drm. Sepeda motor memberikan kecepatan dan kelincahan bergerak, dapat menjual dagangannya lebih jauh, dan menghemat waktu perjalanan. Di wilayah ini banyak dijumpai anakanak, pelajar SD/SMP yang mengendarai sepeda motor ke sekolah maupun untuk kegiatan lain, berkendaraan sendirian atau berboncengan hingga tiga orang tanpa menggunakan helm di jalan-jalan utama. Menurut pak Hdk, banyak orangtua yang membelikan sepeda motor untuk anakanak mereka dengan alasan supaya tidak merepotkan orang tua. Peraturan sekolah melarang anak-anak membawa sepeda motor ke sekolah, tetapi mereka tetap saja bersepeda motor tanpa menggunakan helm dan memarkirkan kendaraannya di rumah warga yang berdekatan dengan sekolah. Situasi tersebut dapat dilihat pada gambar 4 .
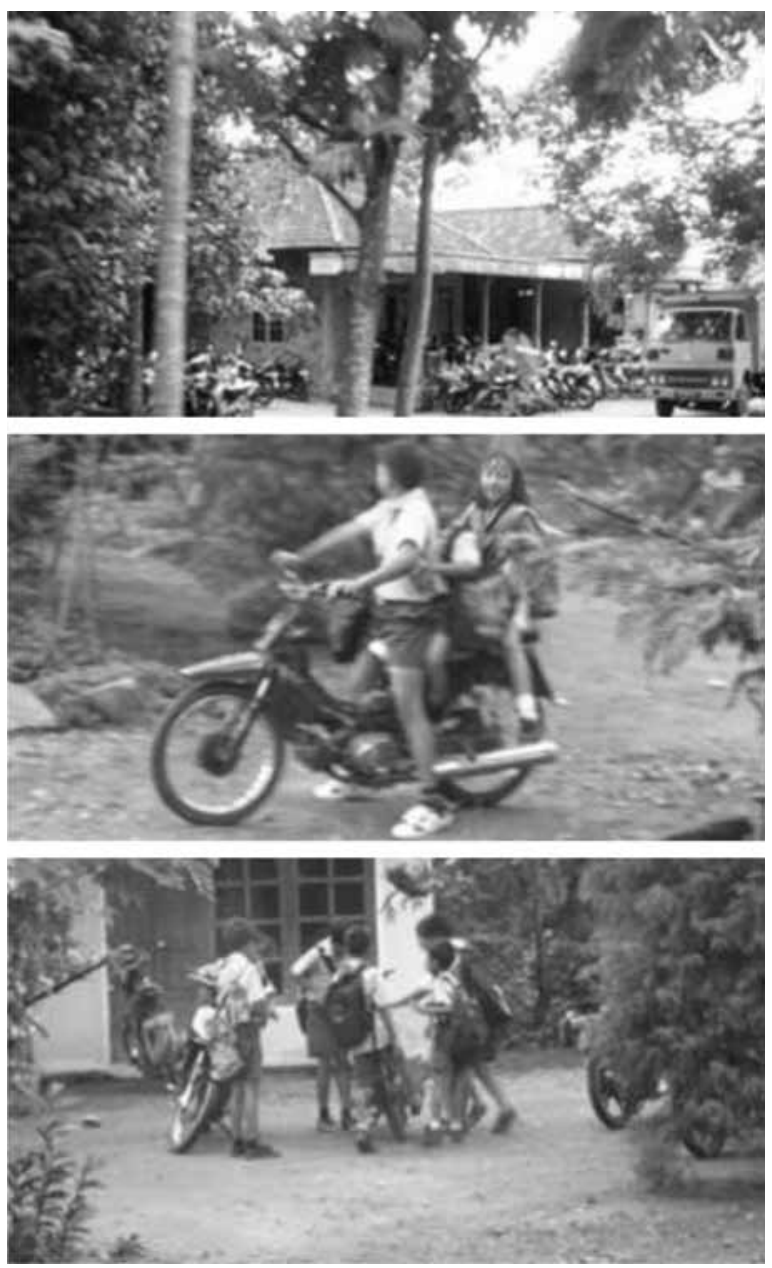

Gambar 4. Penggunaan Sepeda Motor oleh Anak-Anak Sekolah

Meskipun sepeda motor berkembang pesat sebagai layanan transportasi pribadi, kendaraan ini masih juga digunakan sebagai layanan transportasi umum non-formal ('ojek'). Penggunaan sepeda motor telah 
menjadi layanan transportasi dominan, tidak hanya untuk keperluan pergerakan di dalam desa saja (internal), tetapi juga untuk pergerakan keluar desa bahkan ke luar kabupaten (eksternal). Kondisi medan berbukit dengan alinemen jalan berkelokkelok serta naik turun bukan kendala bagi sepeda motor untuk bisa dikendaraai dengan cepat. Mobilitas masyarakat dan aksesibilitas wilayah pada periode ini bisa dikatakan baik, meski muncul dampak negatif berupa menurunnya keselamatan lalu-lintas.

\section{Perubahan Karakter Layanan Transportasi}

Perkembangan layanan transportasi perdesaan dari tahap I hingga III menunjukkan perubahan jenis layanan berawal dari layanan yang lambat (tidak bermotor) menjadi layanan cepat (bermotor) dengan menggunakan sepeda motor untuk layanan pribadi maupun umum. Karakter layanan yang lambat pada tahap I berkembang menjadi lebih cepat (kecepatan sedang) pada tahap II (angkutan umum) dengan wilayah layanan terbatas pada rute tertentu saja dan pada tahap III menjadi layanan kecepatan tinggi dengan wilayah layanan yang luas. Perkembangan terakhir, dominasi layanan sepeda motor, menunjukkan penggunaan yang sangat beragam, bisa untuk layanan pribadi atau umum, layanan angkutan orang atau barang maupun transportasi sosial. Kecepatan yang tinggi didukung oleh kemampuan jelajahnya yang bagus mengakibatkan layanan sepeda motor memiliki -aksesibilitas- paling tinggi dibanding layanan sebelumnya.

Aspek waktu layanan, terjadi perubahan waktu layanan yang semakin panjang, dari semula hanya waktu-waktu tertentu saja (layanan angkutan umum) berubah menjadi sepanjang hari atau setiap saat kapanpun diperlukan tersedia layanan tersebut (layanan sepeda motor). Pemanfaatan layanan transportasi ditunjukkan pula dengan frekuensi layanan yang semakin me- ningkat. Sepeda motor merupakan layanan yang paling sering digunakan untuk berbagai kebutuhan perjalanan maupun pengangkutan. Dengan kata lain, -ketersediaan (availability)-layanan sepeda motor lebih baik dibandingkan layanan transportasi pada tahap sebelumnya. Hal ini dikarenakan sifat kepemilikan sepeda motor yang bersifat pribadi, pemanfaatannya tidak tergantung pihak lain, lebih bebas digunakan sebagai layanan transportasi orang maupun barang serta layanan transportasi pribadi maupun umum.

Perkembangan layanan transportasi ditunjukkan pula oleh jangkauannya yang berubah dari wilayah yang sempit (di dalam desa) menjadi ke berbagai wilayah (ke luar desa) dengan berbagai karakter topografi yang bisa ditempuh sepeda motor. Layanan sepeda motor tersebut diperkuat dengan kemampuan jelajahnya pada berbagai kondisi jalan, seperti: jalan tanah, jalan dengan perkerasan, jalan rusak, jalan baik, jalan sempit maupun jalan lebar. Sepeda motor mampu memberikan layanan transportasi yang sangat -fleksibel-.

Fleksibilitas sepeda motor yang baik tersebut mendorong masyarakat perdesaan lebih sering menggunakan sepeda motor untuk melakukan berbagai perjalanan, baik untuk jarak sangat pendek maupun sangat jauh. Masyarakat bertumpu pada sepeda motor dalam melakukan perjalanan dan kegiatan sehari-hari. Sebelumnya mereka melakukan perjalanan dalam satu hari dalam jumlah terbatas sekarang mereka bisa kemana-mana, kapanpun, dengan lebih leluasa. Situasi ini meningkatkan -mobilitasmasyarakat perdesaan.

Masih tersisa satu aspek penting dalam operasional layanan transportasi, yaitu -keselamatan (safety). Secara mendasar, kecepatan merupakan faktor risiko yang penting (Elvik dan Vaa, 2005). Semakin tinggi kecepatan kendaraan, semakin tinggi risiko kecelakaannya. Perkembangan layanan transportasi yang terjadi menunjukkan per- 
kembangan penggunaan kendaraan yang semakin cepat, makin tinggi kemampuan manuvernya dan semakin besar pula risiko kecelakaannya. Dapat disimpulkan, perkembangan layanan sepeda motor menunjukkan penurunan tingkat keselamatan lalu-lintas, sesuai dengan pernyataan bahwa sepeda motor merupakan kendaraan tidak aman (Oshima dan Fukuda, 2007). Berdasarkan uraian di atas, perkembangan layanan transportasi menunjukkan karakter perkembangan seperti pada Tabel 4 .

Tabel 4.

Karakter Perkembangan Layanan Transportasi

\begin{tabular}{l|l|l|l|l}
\hline \multicolumn{1}{c|}{$\begin{array}{c}\text { Karakter } \\
\text { perkembangan }\end{array}$} & $\begin{array}{c}\text { Periode I } \\
\text { (Kendaraan tidak } \\
\text { bermotor }\end{array}$ & $\begin{array}{c}\text { Periode II } \\
\text { (Angkutan Umum) }\end{array}$ & $\begin{array}{c}\text { Periode III } \\
\text { (sepeda motor) }\end{array}$ & Kesimpulan \\
\hline Aksesibilitas & & Meningkat \\
\hline Ketersediaan & & Meningkat \\
\hline Fleksibilitas & & Meningkat \\
\hline Mobilitas & & Meningkat \\
\hline Keselamatan & & Menurun \\
\hline
\end{tabular}

Sumber: Hasil analisis

Layanan transportasi di wilayah studi menunjukkan adanya perkembangan positif berupa peningkatan aksesibilitas, ketersediaan, fleksibilitas, dan mobilitas. Hanya ada satu perkembangan negatif yaitu penurunan keselamatan lalu-lintas. Konteks wilayah berbukit dan rentan terhadap dampak erupsi gunung Merapi, perkembangan tersebut juga menunjukkan adanya karakter layanan yang mampumengatasikendalaalam. Penggunaan sepeda motor memudahkan masyarakat melakukan perjalanan ke berbagai wilayah terpencil, dengan ketinggian cukup besar yang sebelumnya sulit dijangkau. Sepeda motor juga membantu dalam evakuasi ketika erupsi gunung Merapi, masyarakat dapat mengungsi dengan cepat dan ketika harus menengok rumah, ternak maupun kebun mereka selama di pengungsian tidak bergantung pada angkutan yang disediakan Pemerintah. Sepeda motor telah menjadi sarana untuk menaklukan kondisi wilayah yang sulit serta sebagai sarana untuk menyelamatkan diri pada saat terjadi bencana erupsi gunung Merapi.

\section{SIMPULAN}

Perkembangan layanan transportasi di wilayah studi menunjukkan perbedaan yang signifikan dengan wilayah negara maju yang saat ini didominasi oleh layanan mobil pribadi. Layanan mobil pribadi menunjukkan fleksibilitas lebih rendah dibandingkan dengan layanan sepeda motor. Kemampuan jelajah mobil pribadi terbatas pada jalan-jalan dengan perkerasan baik,lebar minimal tiga meter, kondisi medan tidak terlalu terjal serta biaya operasional kendaraan lebih tinggi dibanding layanan angkutan umum. Layanan sepeda motor memberikan lebih banyak kemudahan bagi masyarakat perdesaan di wilayah perbukitan, termasuk kemampuan mengatasi kendala alam (topografi) dan evakuasi akibat bencana alam yang tidak diperoleh dalam layanan mobil pribadi. Sementara itu, perkembangan layanan transportasi perdesaan di negara-negara sedang berkembang (di luar Indonesia) masih didominasi oleh layanan transportasi pribadi menggunakan kendaraan tidak bermotor dan layanan transportasi umum menggunakan bis kecil atau mini-van. Untuk mengakses angkutan umum tersebut masih 
sangat sulit. Penggunaan sepeda motor sebagai kendaraan pribadi belum ekstensif di Indonesia, sehingga mobilitas masyarakat dan aksesibilitas wilayah masih lebih rendah.

Perkembangan layanan transportasijuga memberikan perubahan karakter layanan baik yang positif (peningkatan ketersediaan, frekuensi, mobilitas, dan aksesibilitas serta mengatasi kendala alam) maupun negatif (penurunan keselamatan lalu-lintas). Karakter positif telah memudahkan masyarakat dalam mengakses berbagai layanan sosial dan ekonomi. Peluang untuk meningkatkan kesejahteraan keluarga semakin terbuka. Hanya saja, sebagian besar masyarakat belum melihat dampak negatif berupa penurunan keselamatan lalu-lintas sebagai satu permasalahan yang besar pada saat ini. Masyarakat perbukitan juga mendapatkan manfaat besar dari perkembangan layanan transportasi berupa kemampuan mengatasi kendala alam dalam melakukan perjalanan serta kemudahan dan kecepatan evakuasi ketika terjadi erupsi gunung Merapi.

Konsekuensi perkembangan sepeda motor berupa penurunan kinerja transportasi umum perdesaan yang menjadi wewenang dan tanggung jawab pemerintah. Sebagai penyedia layanan transportasi, Pemerintah disarankan harus tetap mengembangkan layanan transportasi umum, terutama bagi masyarakat yang tidak memiliki kendaraan pribadi atau tidak bisa menggunakan sepeda motor. Kebijakan subsidi bagi transportasi perdesaan harus dibangun dengan mewajibkan operator transportasi umum perkotaan juga melayani transportasi umum perdesaan dengan menganut sistem subsidi silang. Dengan demikian, setiap anggota masyarakat diharapkan bisa memiliki akses ke layanan transportasi umum. Pada wilayah-wilayah dengan kondisi topografi sangat sulit, Pemerintah bisa berperan lebih besar dalam penyediaan jaringan jalan serta mendorong peran serta masyarakat dalam penyediaan layanan transportasi sosial yang memiliki prinsip saling menolong, tenggang rasa dan gotong-royong. Layanan transportasi sosial menjadi konsep utama pengembangan layanan transportasi perdesaan di wilayahwilayah terpencil, sulit di akses oleh layanan transportasi umum.

Disarankan pula, aspek negatif perkembangan layanan transportasi berupa penurunan keselamatan lalu-lintas harus segera direspon pemerintah dengan langkah-langkah kongkrit seperti peningkatan kedisiplinan berlalu-lintas, control, dan penindakan yang tegas terhadap penyalahgunaan kendaraan bermotor oleh anak-anak atau remaja di bawah usia yang disyaratkan. Kesemrawutan lalu-lintas di jalan sebagai akibat peningkatan jumlah kendaraan bermotor harus diantispasi lebih awal dengan manajemen lalu-lintas. Demikian pula bertambahnya pencemaran lingkungan berupa asap sisa pembakaran bahan bakar kendaraan bermotor dan debu pekat yang menyeliputi jalan-jalan perdesaan akan menurunkan kesehatan masyarakat maupun lingkungan.

\section{DAFTAR PUSTAKA}

Dewanti; Djunaedi, Achmad; Parikesit, Danang, 2013, Strategies of Rural Transport Service Provision, Proceeding The 4th International Conference on Sustainable Future for Human Security - SUSTAIN 2013, Kyoto University, Kyoto, Japan.

Donges, Chris, 2001, Rural Access and Employment. The Laos Expereience, ILO, Geneva.

Elvik, Run; Vaa, Truls, 2004, The Handbook of Road Safety Measures, Elsevier, London.

Halden, Derek; Farrington, John; Copus, Andrew, 2002, Rural Accessibility, Scottish Executive Central Research Unit, Edinburg.

Hancock,DR; Algozzine,B. , 2006, Doing Case Study Reseach: A Practical Guide for Beginning Researchers, Teachers Colledge Press, London. 
Johnston, DC. , 2007, These roads were made for walking? The nature and use of rural public transport services in Garut regency, west java, Indonesia, Singapore Journal of Tropical Geography 28, 2007, 171-187.

Nutley, Stephen, 2005, Monitoring rural travel behaviour: a longitudinal study in Northern Ireland 1979-2001, Journal of Transport Geography 13, 247 263.

Oshima, R. , Fukuda, A. , 2007, Study on Regulation of Motorcycle TaxiService in Bangkok, Journal of the Eastern Asia Society for Transportation Studies, vol 7

Owen, Wilfred, 1987, Transportation and World Development, Hutchinson Education, London.

Porter, G. , 2002, Living in a Walking World: Rural Mobility and Social Equity Issues in Sub-Saharan Africa, World Development, 30-2, 285-300
Porter, G,. 2013, Transport Services and Their Impact on Poverty and Growth in Rural Sub-Saharan Africa, AFCAP/ Durham University.

Sarkar, A. K. ; Ghosh, D. , 2000, Development Debate and Practice: Identification and Prioritisation of Access Problems in Rural Areas, Development Southern Africa Vol 17 No. 1 March 2000.

Starkey, P. , Ellis, S. , Hine, J. , Ternell, A. , 2002, Improving Rural Mobility: Options for Developing Motorized and Nonmotorized Transport in Rural Areas, World Bank Technical Paper.

Williams,C. ; White, R. , 2001, Evaluating the role of the social economy in tackling rural transport problems: some case study evidence from rural England, Planning Practice and Research vol 16, Nos 3 / 4.

Yin, Robert K. , 2009, Case Study Research Design and Method, third edition, Sage Publication, United Kingdom. 